\title{
IDENTIFIKASI ARSITEKTUR TROPIS PADA BANGUNAN LAMA DI JALAN SITI KHADIJAH KOTA BENGKULU
}

\author{
Fitrianty Wardhani ${ }^{1}$, Dwi Oktavallyan ${ }^{2}$ \\ 1,2. Program Studi Arsitektur, Fakultas Teknik, Universitas Bengkulu, \\ Jl. W.R. Supratman, Kandang Limun, Kota Bengkulu \\ Email: fwardhani@unib.ac.id
}

\begin{abstract}
Abstrak
Arsitektur tropis adalah arsitektur yang mencoba memecahkan problematika iklim tropis, hujan deras, terik matahari, suhu udara tinggi, kelembaban tinggi (untuk tropis lembab), kecepatan angin rendah. Perwujudan kota tropis yang berkelanjutan memerlukan desain bangunan yang tanggap lingkungan. Salah satu upaya yang dilakukan adalah pemilihan material dan desain pada tampang bangunan yang sesuai kota tropis. Bangunan-bangunan lama dulunya banyak dibangun menyesuaikan dengan iklim setempat. Salah satu diantaranya adalah bangunan-bangunan lama yang ada di jalan Khadijah yang keberadaannya hampir hilang saat ini. Tujuan dari penelitian ini adalah mengidentifikasi unsur tropikalitas pada bangunan lama yang telah beradaptasi terhadap iklim tropis. Metode yang digunakan dalam penelitian yaitu metode deskriptif kualitatif pada studi kasus melalui observasi dan identifikasi penerapan unsur arsitektur tropis pada wujud luar (orientasi bangunan dan atap) dan wujud dalam bangunan (pola ruang, lantai, dinding dan bukaan). Penelitian ini diharapkan menjawab signifikansi bagi masyarakat untuk mempertahankan bangunan lamanya. Temuan ini diperlukan untuk memberikan alasan logis bagi masyarakat dan pemerintah untuk mengkonservasi bangunan lama yang ada di Kota Bengkulu.
\end{abstract}

Kata kunci: arsitektur tropis, bangunan lama, signifikansi, jalan Khadijah, Kota Bengkulu.

\begin{abstract}
Title: Identify tropical architecture in the old building at Jalan Siti Khadijah Bengkulu City

Tropical architecture tries to deal with the tropical climate problems characterized by heavy rain, blazing sun, high air temperatures, high humidity (for humid tropics), and low wind speeds. The realization of a sustainable tropical city requires building environmentally responsive designs. The efforts could be made, such as selecting materials and models on buildings' external and internal appearance that suit to tropical city. Old buildings used to be built to adapt to the local climate. One of them is the old buildings on Khadijah street, which the existence is almost gone now. This study aims to identify the tropics element in old buildings that have adapted to the tropical climate. The method used in this research is a qualitative descriptive method in case studies through observation and identification of the application of tropical architectural elements in the external appearance (building and roof orientation) and the internal appearance in the building (space, floor, wall, and opening patterns). The aim of this research is to fulfill the arguments for the community about the significance of maintaining the old buildings. This finding is needed to provide a logical reason for the community and government to conserve the old buildings in Bengkulu City.
\end{abstract}

Keywords: tropical architecture, old building, significance, jalan Khadijah, Bengkulu City.

\section{Pendahuluan}

Arsitektur hijau dan Green Urban Design merupakan suatu teori perancangan urban yang mengemukakan

gagasan-gagasan lingkungan hijau sebagai pertimbangan pokoknya. Arsitektur tropis adalah arsitektur yang mencoba memecahkan problematika iklim tropis, hujan deras, 
terik matahari, suhu udara tinggi, kelembaban tinggi (untuk tropis lembab), kecepatan angin rendah. Arsitektur vernakular atau arsitektur tradisional di Indonesia banyak melakukan pendekatan iklim sebagai bagian dari alam, merupakan unsur paling dipertimbangkan bahkan dihormati dalam membangun rumah atau bangunan lainnya.

Sedangkan arsitektur kolonial datang ke Indonesia sehingga terjadi percampuran dari arsitektur Eropa, melalui proses adaptasi dan membentuk arsitektur Belanda pada masa penjajahan di Indonesia. Arsitektur ini telah beradaptasi dengan iklim tropis di Indonesia, guna menyesuaikan dengan lingkungan setempat.

Perwujudan kota tropis yang berkelanjutan memerlukan desain bangunan yang tanggap lingkungan. Salah satu upaya yang dilakukan adalah pemilihan material dan desain pada tampang bangunan yang sesuai kota tropis. Adanya share desain arsitektur lokal dan arsitektur Belanda di Indonesia menghasilkan bangunan berarsitektur campuran yang disebut kolonial (Roosmalen, 2016). Rumah kolonial di Indonesia dikenal memiliki sistem pendinginan pasif lebih baik apabila dibandingkan dengan rumah tradisional (Santosa, 2003).

\section{Metode}

Penelitian ini merupakan jenis penelitian deskriptif kualitatif pada studi kasus. Pengumpulan data dilakukan dengan observasi langsung terhadap obyek penelitian yaitu melakukan pengamatan terhadap bangunan lama yang ada pada jalan Khadijah.

Identifikasi unsur arsitektur tropis pada bangunan dengan memfokuskan pengamatan pada wujud luar bangunan yang meliputi orientasi dan atap serta wujud dalam bangunan, seperti pola ruang, lantai, dinding, bukaan dan plafon. Pengumpulan data studi literatur dilakukan dengan cara membuat measured drawing terhadap bangunan yang diamati.

Tabel 1. Kriteria penerapan arsitektur tropis

\begin{tabular}{|l|l|l|l|l|l|l|}
\hline No. & Orientasi & Bentuk & Material & $\begin{array}{l}\text { Bentuk } \\
\text { Denah }\end{array}$ & $\begin{array}{l}\text { Organisasi } \\
\text { Ruang }\end{array}$ & Bukaan \\
\hline 1. & $\begin{array}{l}\text { Orientasi } \\
\text { matahari }\end{array}$ & Atap & Atap & $\begin{array}{l}\text { Persegi } \\
\text { panjang }\end{array}$ & $\begin{array}{l}\text { Pola } \\
\text { peletakan } \\
\text { ruang }\end{array}$ & $\begin{array}{l}\text { Bukaan bangunan } \\
\text { terhadap matahari }\end{array}$ \\
\hline 2. & $\begin{array}{l}\text { Arah mata } \\
\text { angin }\end{array}$ & Dinding & Dinding & & & Bukaan terhadap udara \\
\hline
\end{tabular}

Sumber : Lisa dan Nurhaiza, 2017

\section{Hasil dan Pembahasan}

Pengamatan dan identifikasi yang kedua ini adalah identifikasi unsur arsitektur tropis pada bangunan dengan memfokuskan pengamatan pada wujud luar bangunan yang meliputi orientasi dan atap serta wujud dalam bangunan, seperti pola ruang, lantai, dinding, bukaan dan plafon. Pengumpulan data dilakukan dengan observasi di lapangan dan wawancara dengan pemilik bangunan. Analisis data dilakukan dengan content analysis. Analisis dimulai dengan menentukan teori yang relevan kemudian diinterpretasikan oleh penulis berdasarkan data yang didapat dengan 
melakukan measured drawing terhadap bangunan yang diamati.

\section{Rumah Dokter Abu Hanifah \\ Matahari: Arah Angin}

Bangunan menghadap ke arah timur. Sehingga, pada pagi hari bagian depan bangunan akan mendapat panas maksimal. Akan tetapi, pada bagian ini didesain dengan kaca yang gelap. Panas dapat tereduksi dengan adanya teras pada bagian depan rumah. Selain itu, vegetasi yang tinggi dan rindang juga diletakkan di depan rumah sehingga dapat menghalangi sinar matahari pada pagi hari.

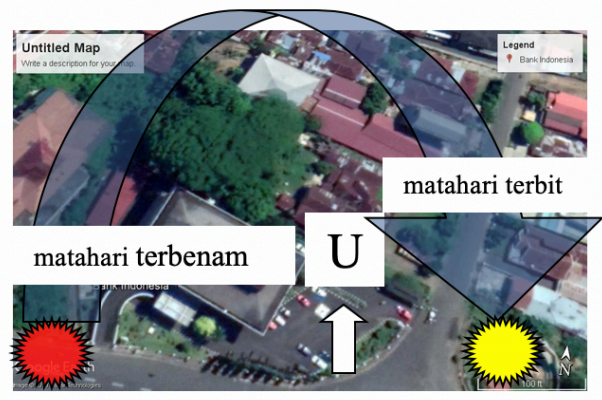

Gambar 1. Orientasi bangunan terhadap matahari

Sumber: Dokumentasi Wardhani, 2019

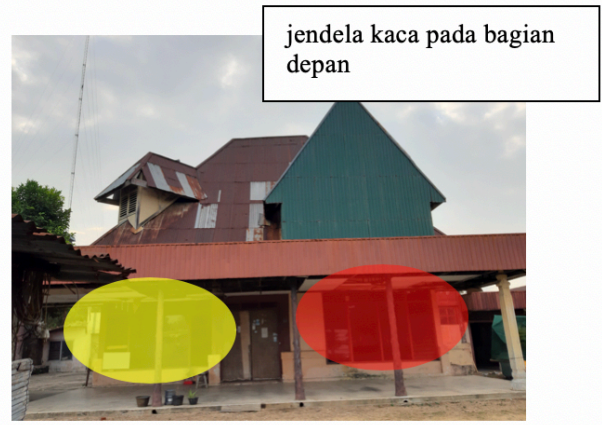

Gambar 2. Material jendela kaca pada bagian depan

Sumber: Dokumentasi Wardhani, 2019

\section{Material: Kemiringan Atap}

Bangunan ini menggunakan material atap dari seng dengan warna biru dan coklat. Warna coklat ini karena atap sengnya telah lama sehingga mengalami perubahan warna bila dilihat pada eksisting sekarang. Sudut kemiringan atap 35 dan 45 derajat sesuai dengan kemiringan atap yang tanggap terhadap iklim tropis dengan curah hujan yang tinggi.

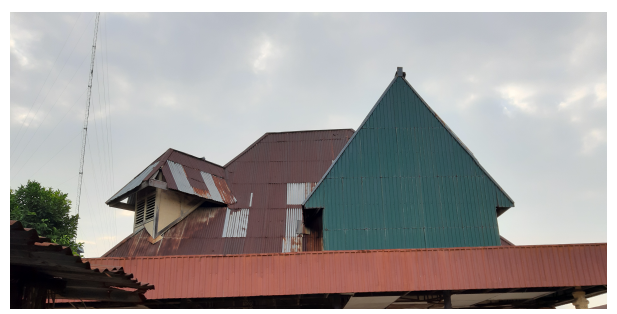

Gambar 3. Material seng pada atap Sumber: Dokumentasi Wardhani, 2019

\section{Konfigurasi Ruang: Material}

Lantai menggunakan material teraso dari marmer. Jika ditinjau dari arsitektur tropis, penggunaan material lantai dari marmer ini memberikan pengaruh dingin pada ruangan karena material teraso marmer ini bersifat dingin dan mampu menyerap panas di dalam ruangan.

Hal yang membedakan antara teraso dan tegel adalah lapisan atas teraso dicampur pecahan batu bermotif (terrazo stone) sehingga pilihan warnanya lebih banyak dibandingkan dengan tegel. Perlu diketahui, asal mula kata teraso berasal dari Italia (terrazza) yang artinya penutup lantai. Di sana, teraso merupakan hasil limbah dari penambangan batu marmer yang diolah kembali menjadi sebuah lantai alternatif.

Material teraso ini memang dibawa dan diperkenalkan oleh Belanda sehingga kebanyakan bangunan peninggalan kolonial menggunakan material lantai teraso, termasuk pada rumah ini. 


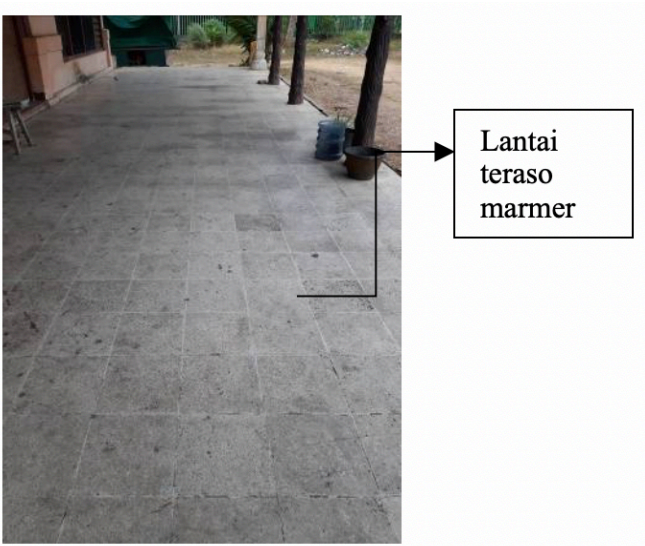

Gambar 4. Material teraso pada lantai Sumber: Dokumentasi Wardhani, 2019

Pada bangunan ini dinding terbuat dari material bata dengan plester semen. Pada iklim tropis, bidang vertikal pada sisi utara dan selatan tidak begitu banyak menerima radiasi panas matahari karena sudut jatuh cahaya cukup besar. Pada siang hari di sisi timur dan pada sore hari di sisi barat radiasi cahaya matahari cukup besar karena sudut jatuh cahaya matahari kecil. Dinding termasuk dalam bidang vertikal dan membentuk konfigurasi ruang. Namun, pada bangunan ini hal tersebut tidak terlalu diperhatikan.

\section{Sistem Bukaan: Dimensi}

Sistem bukaan pada bangunan yaitu pintu, jendela dan ventilasi. Material dan ukuran pintu menjadi salah satu aspek penting yang harus diperhatikan pada bangunan tropis. Kusen dan jendela terbuat dari kayu membingkai kaca mati dan jalusi kaca. Sedangkan pintu berukuran besar sekitar 2,5 meter terbuat dari kayu berbentuk pintu model jalusi. Ukurannya yang besar serta bentuk pintu dengan jalusinya membuat sirkulasi udara di dalam ruangan sangat lancar sehingga di dalam bangunan terasa sejuk. Selain itu, ventilasi yang besar dan lebar juga memungkinkan pertukaran udara yang sangat baik di dalam ruangan.

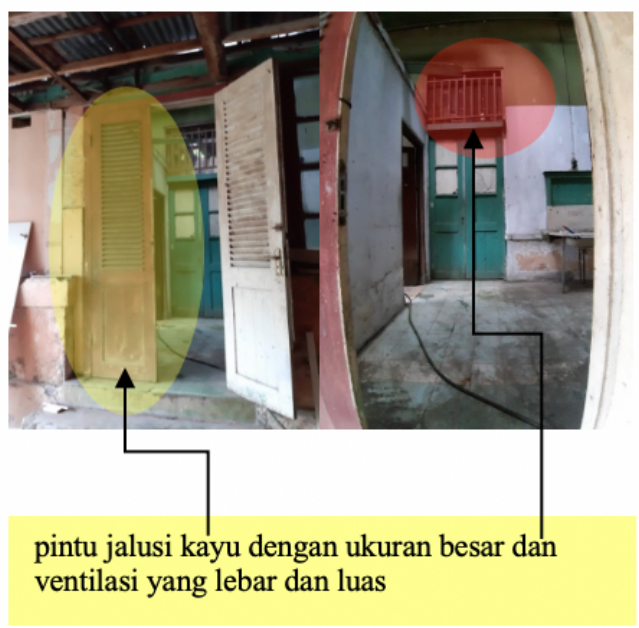

Gambar 5. Material pintu dan ventilasi Sumber: Dokumentasi Wardhani, 2019

\section{Elevasi terhadap Lantai: Material}

Penggunaan material dan ketinggian plafond sangat mempengaruhi aliran udara pada bangunan tropis. Penggunaan material kayu untuk plafond dapat menghambat pancaran udara panas yang terjadi melalui atap. Eksisting material plafond pada bangunan ini menggunakan material triplek dan rangka kayu dengan ketinggian yang relatif tinggi yaitu 3,5 -4 meter.

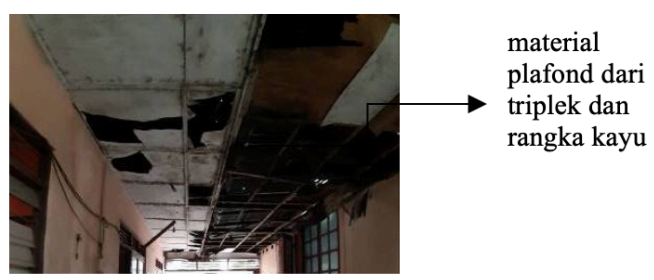

Gambar 6. Material plafond

Sumber: Dokumentasi Wardhani, 2019

\section{SDN 4 Kota Bengkulu}

Matahari: Arah Angin

Bangunan SDN 4 Kota Bengkulu menghadap ke arah barat, sehingga pada sore hari bagian depan bangunan akan mendapat cahaya dan panas maksimal. Posisi ini sangat tepat mengingat bangunan kedua ini berfungsi sebagai sekolah, anak-anak bisa mendapatkan manfaat yang banyak dari sinar matahari pagi. 
Bagian depan bangunan yang berfungsi sebagai ruang kantor dan kepala sekolah ini menggunakan kaca. Konfigurasi ruang seperti ini adalah tepat, sehingga panas tidak terlalu mengganggu untuk aktivitas belajar mengajar.

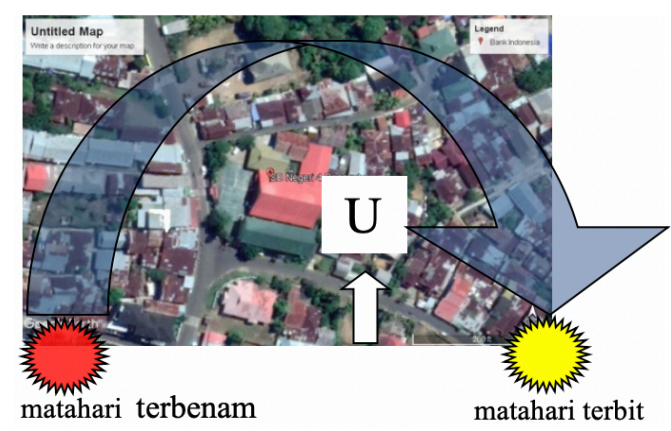

Gambar 7. Orientasi bangunan terhadap matahari dan arah angin Sumber: Dokumentasi Wardhani, 2019

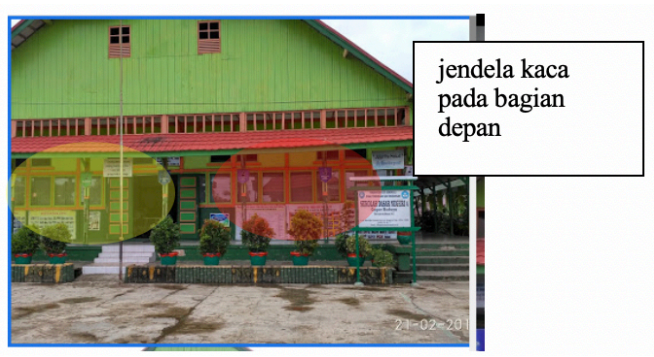

Gambar 8. Material kaca pada jendela Sumber: Dokumentasi Wardhani, 2019

\section{Material: Kemiringan Atap}

Bangunan ini menggunakan material atap seng bila dilihat pada eksisting sekarang. Sudut kemiringan atap mencapai 45 derajat sesuai dengan kemiringan atap yang tanggap terhadap iklim tropis dengan curah hujan yang tinggi. Sudut kemiringan 45 derajat ini menyebabkan atap menjadi sangat tinggi dan bangunan terkesan monumental. Selain itu, ruang yang berada di bawahnya juga menjadi sejuk dan tidak panas.

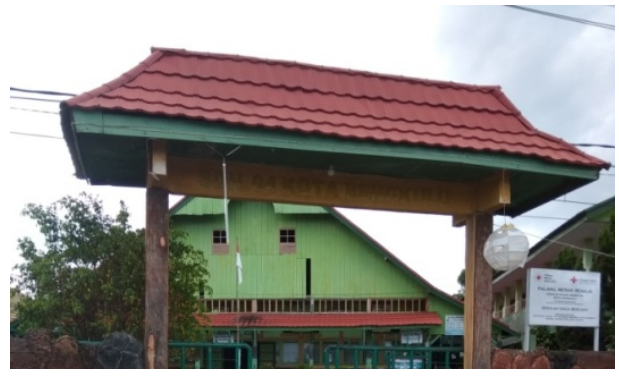

Gambar 9. Sudut kemiringan atap Sumber: Dokumentasi Wardhani, 2019

\section{Konfigurasi Ruang: Material}

Material lantai menggunakan teraso. Ditinjau dari arsitektur tropis, penggunaan material lantai dari teraso ini memberikan pengaruh dingin pada ruangan. Material teraso marmer ini dapat memberikan rasa dingin saat udara panas dan dapat memberikan rasa panas saat udara dingin, juga mampu menyerap panas di dalam ruangan. Material teraso ini memang dibawa dan diperkenalkan oleh Belanda, sehingga kebanyakan bangunan peninggalan kolonial menggunakan material lantai teraso ini, termasuk pada SDN 4 Kota Bengkulu ini.

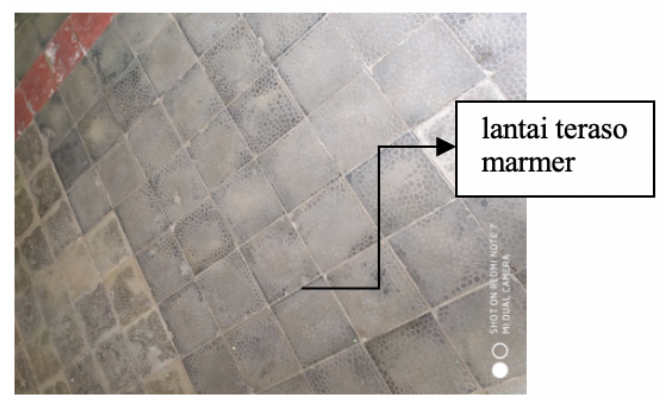

Gambar 10. Material lantai

Sumber: Dokumentasi Wardhani, 2019

Pada bangunan ini dinding terbuat dari material bambu yang disusun kemudian diplaster yang dinamakan bidai. Meskipun menggunakan material bambu, tetapi penggunaannya hampir sama dengan dinding bata. Dinding termasuk dalam bidang vertikal dan membentuk konfigurasi 
ruang. Namun pada bangunan ini hal tersebut tidak terlalu diperhatikan.

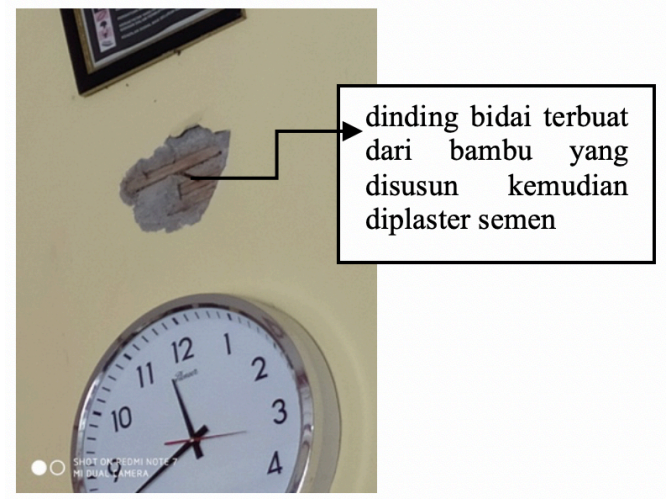

Gambar 11. Dinding bidai dari bambu Sumber: Dokumentasi Wardhani, 2019

\section{Sistem Bukaan: Dimensi}

Dilihat dari bentuknya, pintu bangunan ini berbentuk pintu dan jendela jalusi kayu. Kusen, pintu dan jendela terbuat dari kayu, pintu berukuran standar sekitar 2 meter. Bentuk pintu dengan model jalusi memungkinkan sirkulasi udara di dalam ruangan sangat lancar sehingga di dalam bangunan terasa sejuk. Selain itu, ventilasi besar dan lebar yang hanya menggunakan kawat membuat hampir tidak ada perbedaan antara udara di luar dan di dalam bangunan.

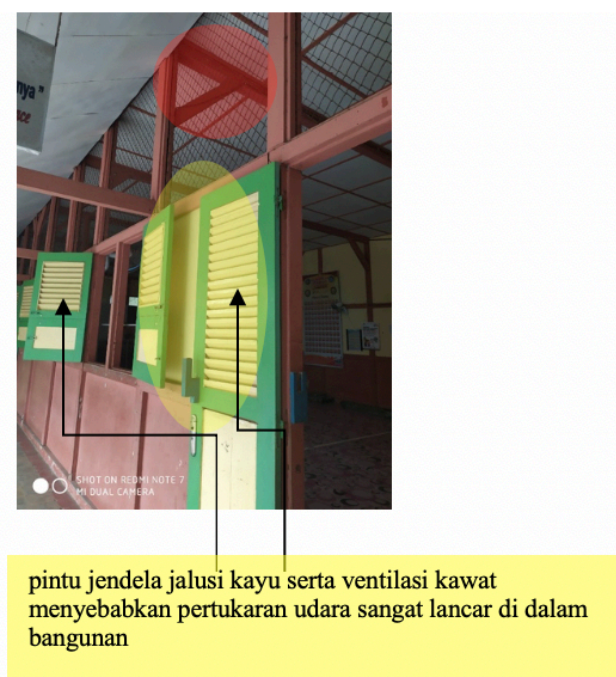

Gambar 12. Pintu dan jendela dari material jalusi kayu

Sumber: Dokumentasi Wardhani, 2019
Elevasi terhadap Lantai: Material

Penggunaan material dan ketinggian plafond sangat mempengaruhi aliran udara pada bangunan tropis. Penggunaan material kayu untuk plafond dapat menghambat pancaran udara panas yang terjadi melalui atap. Eksisting material plafond pada bangunan ini menggunakan material triplek dan rangka kayu dengan ketinggian standar yaitu $3-3,5$ meter.

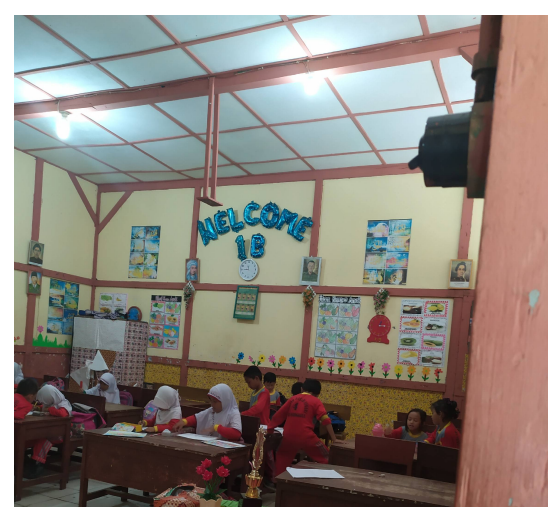

Gambar 13. Material plafond dari triplek dan rangka kayu

Sumber: Dokumentasi Wardhani, 2019

\section{Rumah Pak Zaidin}

Matahari: Arah Angin

Bangunan ini menghadap ke arah barat, sehingga pada sore hari bagian depan bangunan akan mendapat cahaya dan panas maksimal. Pada bangunan ini terdapat jendela kaca di bagian depan sebagai ornamen pada dormer bangunan. Penggunaan material kaca pada jendela kurang tepat karena dapat menyebabkan panas maksimal di dalam ruang pada sore hari. Akan tetapi, pada bagian depan lainnya yang berfungsi sebagai ruang tamu menggunakan jendela jalusi dengan kaca gelap dan berukuran kecil. Bukaan yang kecil pada bagian ini tidak terlalu mempengaruhi suhu udara di dalam ruang tamu tersebut. 


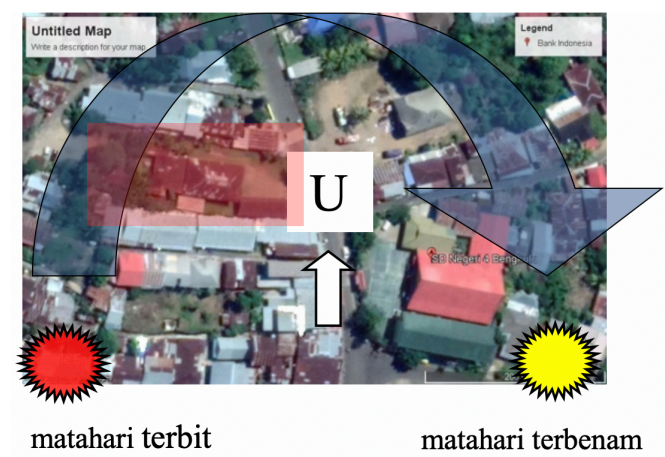

Gambar 14. Orientasi bangunan terhadap matahari dan arah angin

Sumber: Dokumentasi Wardhani, 2019

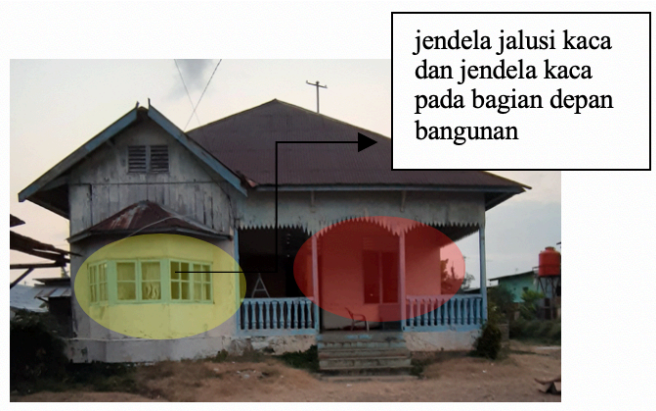

Gambar 15. Material jendela

Sumber: Dokumentasi Wardhani, 2019

\section{Material: Kemiringan Atap}

Bangunan ini menggunakan material atap dari seng bila dilihat pada eksisting sekarang. Sudut kemiringan atap mencapai 35 derajat sesuai dengan kemiringan atap yang tanggap terhadap iklim tropis dengan curah hujan tinggi. Selain itu, sudut kemiringan 35 derajat ini menyebabkan ruang yang berada di bawahnya menjadi sejuk dan tidak panas.

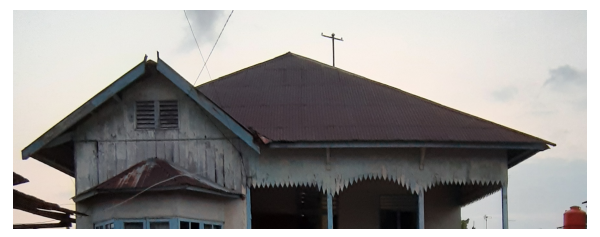

Gambar 16. Material dan kemiringan atap Sumber: Dokumentasi Wardhani, 2019

\section{Konfigurasi Ruang: Material}

Berbeda

sebelumnya, dengan

$$
\text { material }
$$

bangunan

menggunakan
Ditinjau dari konsep arsitektur tropis, penggunaan material cor semen ini memberikan dingin pada ruangan. Meskipun tidak sebaik lantai teraso dalam hal pengaruh dingin, tetapi lantai cor semen biasa ini murah dan mudah perawatannya.

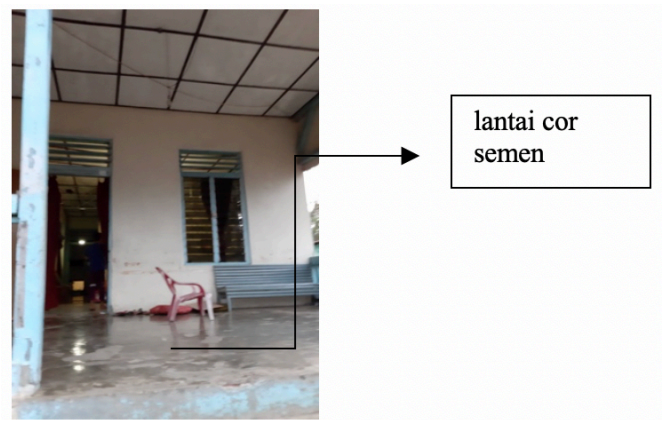

Gambar 17. Material lantai teras depan Sumber: Dokumentasi Wardhani, 2019

Pada bangunan ini dinding terbuat dari material bata yang disusun kemudian diplester. Bata yang digunakan merupakan bata yang berukuran besar jika dibandingkan dengan bata yang ada di pasaran saat ini. Dinding termasuk dalam bidang vertikal dan membentuk konfigurasi ruang. Namun, pada bangunan ini hal tersebut tidak terlalu diperhatikan.

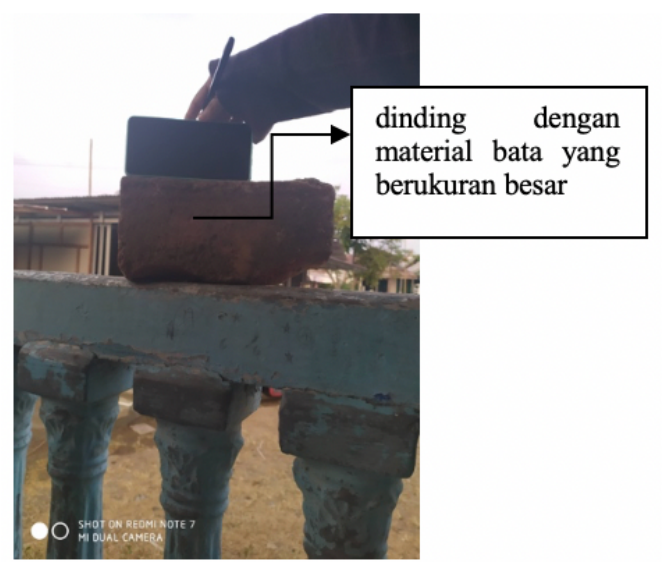

Gambar 18. Perbandingan material bata yang digunakan dengan bata yang ada di pasaran saat ini

Sumber: Dokumentasi Wardhani, 2019 
Elevasi terhadap Lantai: Material

Penggunaan material dan ketinggian plafond sangat mempengaruhi aliran udara pada bangunan tropis. Penggunaan material kayu dan triplek pada plafond dapat menghambat pancaran udara panas yang terjadi melalui atap. Eksisting material plafond pada bangunan menggunakan material triplek dan rangka kayu dengan ketinggian yang relatif tinggi yaitu 4 meter sehingga udara di dalam ruangan menjadi sejuk.

Dengan demikian, hasil identifikasi ketiga bangunan pada jalan Siti Khadijah adalah sebagai berikut:

Tabel 1. Hasil identifikasi unsur arsitektur tropis pada bangunan lama di jalan Siti Khadijah

\begin{tabular}{|l|l|c|c|c|}
\hline No. & \multicolumn{1}{|c|}{$\begin{array}{c}\text { Para- } \\
\text { meter }\end{array}$} & $\begin{array}{c}\text { Bangunan } \\
\mathbf{1}\end{array}$ & $\begin{array}{c}\text { Bangunan } \\
\mathbf{2}\end{array}$ & $\begin{array}{c}\text { Bangunan } \\
\mathbf{3}\end{array}$ \\
\hline 1. & $\begin{array}{l}\text { Orientasi } \\
\text { hunian }\end{array}$ & $\sqrt{ }$ & $\sqrt{ }$ & $\sqrt{ }$ \\
\hline 2. & Atap & $\sqrt{ }$ & $\sqrt{ }$ & $\sqrt{ }$ \\
\hline 3. & Lantai & $\sqrt{ }$ & $\sqrt{ }$ & $\sqrt{ }$ \\
\hline 4. & Dinding & $\sqrt{ }$ & $\sqrt{ }$ & $\sqrt{ }$ \\
\hline 5. & $\begin{array}{l}\text { Bukaan } \\
\text { dan } \\
\text { ventilasi }\end{array}$ & $\sqrt{ }$ & $\sqrt{ }$ & $\sqrt{ }$ \\
\hline 6. & Plafond & $\sqrt{ }$ & $\sqrt{ }$ & $\sqrt{ }$ \\
\hline
\end{tabular}

Sumber: Hasil analisis penulis, 2019

\section{Kesimpulan}

Wujud konsep arsitektur tropis pada bangunan lama yang ada di jalan Khadijah diaplikasikan melalui bentuk wujud luar dan dalam bangunan. Pada wujud luar dapat dilihat dari orientasi hunian dan atap bangunan. Sedangkan pada wujud dalam bangunan dapat dilihat pada lantai, dinding, bukaan dan ventilasi serta plafond. Dari hasil identifikasi diketahui bahwa bangunan yang mengadopsi arsitektur tradisional
Bengkulu dan arsitektur kolonial Belanda memenuhi unsur arsitektur tropis. Kenyamanan thermal dapat dirasakan pada bangunan tanpa harus menggunakan pendingin ruangan. Kenyamanan thermal ini didapatkan melalui penggunaan material lantai teraso dan cor semen biasa, plafond yang terbuat dari rangka kayu dan tripleks dengan ketinggian rata-rata diatas 3,5 meter sehingga perputaran udara lancar di dalam ruangan. Bukaan yang menggunakan pintu dan jendela jalusi kayu menyebabkan udara luar dapat masuk ke dalam bangunan, serta ventilasi yang lebar juga mendukung kenyamanan thermal di dalam ruangan. Sedangkan atap yang tinggi baik untuk daerah dengan curah hujan tinggi seperti di Bengkulu dan kemampuan untuk menahan panas dari atas pada siang hari sangat tepat digunakan di daerah Bengkulu.

\section{Daftar Pustaka}

Lisa, N.P. dan Nurhaiza. (2017). Pengaruh adaptasi arsitektur tropis pada bangunan kolonial di koridor jalan Blang Mee Samudera Pase. Prosiding Seminar Heritage IPLBI 2017, 1, B111-118.

Van Roosmalen, Pauline K.M. (2016). Laura Victoir and Victoir Zatsepine (Eds.), Harbin to Hanoi: The colonial built environment in Asia, 1840 to 1940. ABE Journal Architecture beyond Europe (online), 9-10, 2016. Diakses 18 Juli 2019, dari database http://journals.openedition.org/abe $/ 3071$

Santosa, M. (2003). Totalitas arsitektur tropis, tradisi, modernitas dan teknologi. Pidato Pengukuhan untuk Jabatan Guru Besar dalam Bidang Ilmu/ Mata Kuliah Sains Arsitektur pada FTSP ITS. Surabaya: ITS Press. 